\title{
Biotechnology: a non-existing word/world for the Brazilian deaf community
}

\author{
Ruth Mariani ${ }^{*}$, Cristina Maria Delou ${ }^{1}$, Andressa da Silva Souza ${ }^{2}$, Valentinne Rodrigues Valentim², \\ Deivid dos Passos ${ }^{2}$, Andreza Rosa ${ }^{2}$, Larissa de Oliveira Farias², Karoline Farias Marrocos Moraes², \\ Helena Carla Castro ${ }^{1}$
}

From 5th Congress of the Brazilian Biotechnology Society (SBBIOTEC)

Florianópolis, Brazil. 10-14 November 2013

\section{Background}

Biotechnology is a complex theme that is directly or indirectly present in our lives, from food to medicine. Despite that, the understanding about biotechnology is still difficult for most of society due to this complexity. This is worsened for Brazilian deaf community since the word Biotechnology does not exist in Brazilian Sign Language (LIBRAS), the official deaf language. This young language, similar to some foreigner Sign languages, still misses several scientific terms/words [1]. These terms have to be created by the deaf community to help them guarantee the information access, their citizens rights and a better academic formation [1,2]. Therefore, our purpose as a group formed by deaf and hearing people is to suggest a sign for the word Biotechnology to help on the understanding of the biotechnological area.

\section{Methods}

Initially six deaf students from a public high school were invited to participate in this work as requested by the deaf community for this type of project. To guarantee their understanding, we created a class about this theme in an inquiry-oriented teaching way, also using materials for contextualization (e.g. bottle of transgenic vegetal oil) $[1,3]$.

\section{Results and conclusions}

LIBRAS is a language whose signs represent the concept of the words $[2,4]$. Therefore the word should be previously fully understood by deaf before creating the respective sign. The six deaf students that participated in this work are from a previous stimulated environment, the project Spreadthesign (http://www.spreadthesign.com), an

Programa de Pós-Graduação em Ciências e Biotecnologia, Instituto de Biologia, Universidade Federal Fluminense, RJ, Brazil

Full list of author information is available at the end of the article international dictionary of 25 different sign languages from several countries now including LIBRAS from Brazil with our participation. We were also helped by an interpreter that always interrupted the class when one concept seemed to be not fully understood. Thus, cheese production, the snake venom biotechnological potential, the creation of transgenics for food production, and the insulin biotechnological production were fully discussed in this class. In the end, three signs for Biotechnology emerged: a) the combination of the sign of biology - right hand signing the letter B spinning around slightly in the air - with another movement; so the final sign is the right hand in the position of letter B (for Bio) rubbed in the palm of the left hand, to remind the process of generating some product using biotechnological methods; b) They used dactylology for the letters B, I and O and the sign of technology (hands in the position of letter $\mathrm{T}$ slightly spinning in front of each other). Finally, c) the combination of the sign meaning life - right hand with fingers together on the left shoulder - for Bio, followed by the sign of technology described above. After those sign propositions construction, they decided to send them to the Brazilian Biotechnology Society Event ( $5^{\text {th }}$ SBBiotec) to ask for the society analysis and oppinion. As citizens, deaf community should be allowed to understand the implications of the major changes brought about by biotechnological advances [3-5] and on that matter, the creation of this and other scientific signs may help this community on guarantee the access and understand of current biotechnological information.

\section{Authors' details}

'Programa de Pós-Graduação em Ciências e Biotecnologia, Instituto de Biologia, Universidade Federal Fluminense, RJ, Brazil. ${ }^{2}$ Laboratório de Antibióticos, Bioquímica, Ensino e Modelagem Molecular, Instituto de Biologia, Universidade Federal Fluminense, RJ, Brazil. 


\section{References}

1. Pinto-Silva FE, Martins PRS, Rumjanek VM: Rousing interest in science among secondary school deaf students. Scholarly Journal of Scientific Research and Essay (SJSRE) 2013, 2(7):104-108.

2. Hauland H, Allen C: Deaf people and Human Rights. Report of the World Federation of the Deaf 2009.

3. Bell T, Urhahne D, Schanze S, Ploetzner R: Collaborative Inquiry Learning: Models, tools, and challenges. International Journal of Science Education 2010, 32:349-377.

4. Rocha SM: O INES e a educação de surdos no Brasil: aspectos da trajetória do Instituto Nacional de Educação de Surdos em seu percurso de 150 anos. 2 edition. Rio de Janeiro: INES; 2008.

5. Smith DV, Gunstone RF: Science Curriculum in the Market Liberal Society of the Twenty-first Century: Re-visioning the Idea of Science for All. Research Science Education 2009, 39:1-16.

doi:10.1186/1753-6561-8-S4-P262

Cite this article as: Mariani et al: Biotechnology: a non-existing word/ world for the Brazilian deaf community. BMC Proceedings 2014 8(Suppl 4):P262.

\section{Submit your next manuscript to BioMed Central} and take full advantage of:

- Convenient online submission

- Thorough peer review

- No space constraints or color figure charges

- Immediate publication on acceptance

- Inclusion in PubMed, CAS, Scopus and Google Scholar

- Research which is freely available for redistribution

Submit your manuscript at www.biomedcentral.com/submit
C Biomed Central 